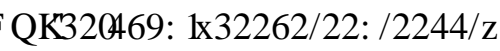

\title{
CONTRIBUTION TO AVAILABILITY ASSESSMENT OF COMPLEX SYSTEMS WITH ONE SHOT ITEMS
}

\section{PŘÍSPĚVEK K HODNOCENÍ POHOTOVOSTI SLOŽITÝCH SYSTÉMŮ S PRVKY JEDNORÁZOVÉHO POUŽITÍ}

\author{
Valis David $^{1}$, Koucky Miroslav ${ }^{2}$ \\ (1) University of Defence, Faculty of Military Technologies \\ Univerzita Obrany, Fakulta vojenských technologií \\ 61200 Brno, Czech Republic \\ (2) Technical University in Liberec, Pedagogic Faculty \\ Technická univerzita v Liberci, Pedagogická fakulta \\ 46117 Liberec, Czech Republic
}

e-mails: (1) david.valis@unob.cz, (2) miroslav.koucky@tul.cz

\begin{abstract}
As we use complex systems with one shot items in many technical applications we need to know basic characteristics of such a system. Performance, safety and others are as much important as dependability measures. As the one shot item is supposed to back up the main system function the total reliability of the system should be higher then. The paper will present a theoretical approach to determining the complex system task/mission success probability rather than a theoretical approach to determining the dynamic reliability (operational availability), and then a practical example.
\end{abstract}

Keywords: Reliability and Availability Assessment, Dynamic Characteristics, One Shot Item.

Streszczenie: Jelikož používáme složité systémy s prvky jednorázového použití $\mathrm{v}$ mnoha technických aplikacích, potřebujeme znát základní charakteristiky takových systémů. Výkon, bezpečnost a ostatní jsou stejně důležité jako vlastnosti spolehlivosti. Z důvodu předpokladu toho, že prvek jednorázového použití má podporovat hlavní funkci systému, předpokládáme, že celková spolehlivost systému bude potom větší. Tento př́spěvek prezentuje teoretický př́stup $\mathrm{k}$ hodnocení pravděpodobnosti úspěchu splnění úkolu/mise spolu s teoretickým př́stupem pro stanovení dynamické bezporuchovosti (provozní pohotovosti) a také praktický prríklad.

Słowa kluczowe: Hodnocení bezporuchovosti a pohotovosti, Dynamické charakteristiky, Prvky jednorázového použití 


\section{CONTRIBUTION TO AVAILABILITY ASSESSMENT OF COMPLEX SYSTEMS WITH ONE SHOT ITEMS}

\section{Introduction}

This contribution is supposed to contribute to a solution of dependability qualities of the complex (in this case) weapon system as an observed object. We would like to show one of the ways how to specify a value of single dependability measures of a set. The aim of our paper is to verify the suggested solution in relation to some functional elements which influence fulfillment of a required function in a very significant manner. [4]

The paper contents deals with a weapon set which is a complex mechatronics system, designed and constructed for military purposes. We are talking about a barrel shooting gun - a fast shooting two-barrel cannon. It is going to be implemented in military air force in particular.

Generally speaking the set consists of mechanical parts, electric, power and manipulation parts, electronic parts and ammunition. For the purpose of use in our paper we are not going to deal with isolated functional blocks and ammunition only. In this case we consider the ammunition as the key element in the whole process as recommended standardized rounds and pyrotechnic cartridges.

Single parts of the set can be described with qualitative and most importantly quantitative indices which present their quality. In this paper we are dealing especially with quality in terms of dependability characteristics. We have been working first and foremost with probability values which characterize single indices, and which describe functional range and required functional abilities of the set. We do not focus only on the part handling rounds and pyrotechnic cartridges which are crucial for this case. In order to continue our work it is necessary to define all terms and specify every function.

The main type of data which can be found in the area of dependability statistical analysis is as follows: simple, censored, cut (reduced) data, or the combination of it.

Simple data: It is a basic category in which the established information $t_{1}$, $t_{2}, \ldots, t_{n}$ is the random sample from probability distribution of time to failure $T$. 
Censored data: $\quad$ The data is designated $\left(t_{1}, d_{1}\right), \ldots,\left(t_{n}, d_{n}\right)$, where $t_{i}=$ min $(T, C), T$ is a random variable determining time to failure, $C$ is censoring time and $d_{i}$ is an indicator defined by the formula $d_{i}=1$, if $t_{i}$ is time fo failure and $d_{i}=0$ in other cases. The basic types include censoring by fixed time ( $C$ is fixed time) and random time ( $C$ is a random variable with given probability distribution). This type of reliability data is frequently used in practice and it can be found in the situations where the observing time is terminated after some time, because the system is put out of operation, etc. Concerning laboratory tests these are the so called tests terminated by time.

Truncated data: This is the data of the failures registered after some time passes. In practice one can come in contact with this sort of data when the information about failures is not put in the early stages.

Classification of statistical methods used in dependability statistical analysis:

Parametric methods: These methods proceed from the assumption that the observed data reflect random selection of the specific distribution type (exponential, Weibull's, gama, etc.). The main task then is to determine (estimate) values of unknown parameters based on the observed data.

Non-parametric methods: These methods do not take into account any specific classification of data and they are a "universal" alternative to parametric methods (their main advantage). The main disadvantage is their smaller power (when compared to parametric methods).

Semi-parametric methods: These methods which are a sort of compromise between parametric and non-parametric methods require only a "partial" specification of the distribution. A parametric model is introduced for important variables and a non-parametric one is introduced for these of minor importance.

\section{Esential terms, definitions and signs}

We are always talking about an object in terms of reliability analyses. The definition for object is the same as the used in IEC 60500 (191/50). Consequently we need to describe the basic object's measures [4];

Object's function:

The main function: The main function of the object is putting into effect a fire from a gun using standard ammunition.

The step function: Manipulation with ammunition, its charging, initiation, detection and indication of ammunition failure during initiation, initiation of backup system used for re-charging of a failed cartridge. 
It is expected that the object will be able to work under different operating conditions especially in different temperature spectra, under the influence of varied static, kinetic and dynamic effects, in various zones of atmospheric and weather conditions.

In this case we will not take into account any of the operating conditions mentioned above. However, their influence might be important while considering successful mission completion.

One of the main terms we are going to develop is:

Mission: It is an ability to complete a regarded mission by an object in specified time, under given conditions and in a required quality.

In our contribution it is a case of cannon ability to put into effect a fire in a required amount - in a number of shot ammunition at a target in required time, and under given operating and environmental conditions.

As it follows from the definition of a mission it is a case of a set of various conditions which have to be fulfilled all at once in a way to satisfy us completely. Our object is supposed to be able to shoot a required amount of ammunition which has to hit the target with required accuracy (probability). We will not take into consideration circumstances relating to evaluation of shooting results, weapon aiming, internal and external ballistics, weather conditions and others. We will focus only on an ability of the object to shoot. [4]

As we have stated above we will not deal with isolated function blocks only. We are presuming that these blocks act according to required and determined boundary conditions. In order to understand functional links fully we introduce our way of dividing the object although we will understand the object as a complex system in the paper.

We speak about the following blocks:

Manipulation with ammunition, its charging, initiation, failure detection and indication during initiation, initiation of a backup system in order to recharge a failed cartridge, all mechanical parts, all electric and electronic parts, interface elements with a carrying device - Block A;

Ammunition - Block B;

Pyrotechnic cartridges - Block C.

Symbols used in the text:

$T \quad$ random variable expressing time to failure,

$t_{1}, t_{2}, \ldots, t_{n}$ observed values of a random variable $T$ (that is a random sample of $T$ ), or data on possible censoring,

$t_{(1)}, t_{(2)}, \ldots, t_{(n)}$ ordered values $t_{1}, t_{2}, \ldots, t_{n}$ (including data on censoring), 
$t_{[1]}, t_{[2]}, \ldots \quad$ ordered random sample of times to failure, that is, without data on censoring,

$\Lambda_{T}(t), \Lambda_{T}^{*}(t) \quad$ cumulative hazard function or its point estimator,

$R_{T}(t), R_{T}^{*}(t) \quad$ reliability function or its point estimator,

$E[\bullet], E^{*}[\bullet] \quad$ mean value of a random variable or its point estimator,

$\operatorname{var}[\bullet] \operatorname{var}^{*}[\bullet]$ variance, or its point estimator $\bullet$.

\section{Description of the process}

The process as a whole can be described this way:

From a mathematical and technical point of view it is a fulfilling of requirements' quee which gradually comes into the service place of a chamber. The requirements' quee is a countable rounds' chain where the rounds wait for their turn and are transported from the line where they wait in to a service place (fulfilment of a requirement) of a chamber and there they are initiated. After the initiation the requirement is fulfilled. An empty shell (one of the essential parts of a round) leaves a chamber taking a different way than a complete round. When the requirement is fulfilled, another system which is an integral part of a set detects process of fulfilling the requirement. The process is detected and indicated on the basis of interconnected reaction processes. In this case fulfilling the requirement is understood as a movement of a barrel breech going backwards. Both fulfilling the requirement and its detection are functionally connected with transport of another round waiting in a line to go into a chamber.

Let's presume that rounds are placed in an ammunition feed belt of an exactly defined length. A maximum number of rounds which could be placed in a belt is limited by the length then. The length is given either by construction limitations or by tactical and technical requirements for a weapon set. Let's presume that despite different lengths of an ammunition belt, this will be always filled with rounds from the beginning to the end. Let's also assume that the rounds are not non-standard and are designed for the set.

The process of fulfilling the requirement is monitored all the time by another system which is able to differentiate if it is fulfilled or not. The fulfillment itself means that a round is transported into a chamber, it is initiated, shot, and finally an empty shell leaves a chamber according to a required principle. If the process is completed in a required sequence, the system detects it as a right one. 
Because of unreliability of rounds the whole system is designed in the way to be able to detect situations in which the requirement is not fulfilled in a demanded sequence and that is why it is detected as faulty.

Although a round is transported into a chamber and is initiated, it is not fired. A function which is essential for a round to leave a chamber is not provided either, and therefore another round waiting in line cannot be transported into a chamber. That is the reason why fulfilling of the requirement is not detected.

The system is designed and constructed in such a way that it is able to detect an event like this and takes appropriate countermeasures. A redundant system which has been partly described above is initiated. After a round is initiated and the other steps don't carry out (non-fire, non-movement of a barrel breech backwards, non-detection of fulfilling the requirement, nonleaving of a chamber by an empty shell, and non-transport of another round into a chamber) a system of pyrotechnic cartridges is initiated. It is functionally connected with all the system providing mission completion. A pyrotechnic cartridge is initiated and owing to this a failed round is supposed to leave a chamber. A failed functional link is established and another round waiting in line is transported into a chamber.

In order to restore the main function we use a certain number of backup pyrotechnic cartridges. Our task is to find out a minimum number which is essential for completing the mission successfully. Next issue we are supposed to solve is to find out the availability function of the system. We would like to know if the system is capable to carry out next mission with its technical/mission "history". If the operational unit left are much enough to complete the task successfully from the technical point of view without any impact on terms of repair/replacement, etc. As based onto the collected data observed from previous deployment and initial operation period of the system we might use standard mathematical tools for their assessment. Due to specific system construction and specific process procedure it seems to us that another than common methods are to be applied. Following session is the example of our effort. [4]

\section{Mathematical model}

Since the data on system operation and process behavior is available we use two methods while analyzing this. The first one is the Nelson - Altsschuler estimator [1], [2], [3]. It is a case of one of the basic non-parametric methods which are used for statistical reliability analysis, especially while 
estimating cumulative hazard function $\Lambda_{T}(t)$. It is defined by following formulae:

$\Lambda_{T}(t)=\int_{0}^{t} \lambda_{T}(u) d u$

where $\lambda_{T}(t)$ is failure rate at the time $t$, thus $\lambda_{T}(t)=\lim _{h \rightarrow 0+} \frac{P(t \leq T<t+h \mid t \leq T)}{h}$. Let us assume that the obtained reliability data $t_{1}, t_{2}, \ldots, t_{n}$ are the information on time to failure or time information about censoring. In this case the Nelson-Altschuler's (N-A) point estimator $\Lambda_{T}^{*}(t)$ of the cumulative failure rate is expressed by

$$
\Lambda_{T}^{*}(t)=\sum_{\substack{[i] \\ t_{[i]} \leq t}} \frac{m_{[i]}}{r_{[i]}},
$$

where $t_{[i]}$ is the $i$-th element of the ordered random sample of times to failure (that is we do not include censoring times in the selection), $m_{[i]}$ is frequency of the value $t_{[i]}$,

$\eta_{i]}$ is number of objects in operation to the time $t_{[i]}$.

If the failure occurs together with the censoring, we assume that the censoring occurs straight after the failure. In order to estimate the variance $\Lambda_{T}^{*}(t)$ we use the asymptotic formula

$$
\operatorname{var}^{*}\left[\Lambda_{T}^{*}(t)\right]=\sum_{\substack{\left.[i] \\ \tau_{i j}\right] \leq t}} \frac{m_{[i]}}{\eta_{i]}^{2}},
$$

through which we determine confidence limits. For $(1-\alpha) \%$ confidence limits of the value $\Lambda_{T}^{*}(t)$ we get

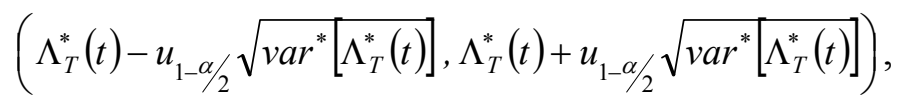

where $u_{\alpha}$ is $\alpha \%$ a quantile of standard normal distribution.

Of course there is large variety of other non-parametric methods which are suitable for dependability assessment based on operational data. These are for example non-parametric renewal density estimations, renewal functions and non-parametric trend tests.

Another method used for the system assessment is determining the distribution of time to failure and its properties. This is the statistical test TTT (Total Time on Test-plot) which allows us to decide whether 
distribution of time to failure is of increasing (IFR - Increasing Failure Rate), or decreasing (DFR - Decreasing Failure Rate) failure rate. If $t_{(1)}, t_{(2)}, \ldots, t_{(n)}$ is an ordered sample of times to failure, then the test statistic $u_{(i)}$ is defined as follows:

$u_{(i)}=\frac{T_{i, n}}{T_{n, n}}$,

where $T_{i, n}=t_{(1)}+t_{(2)}+\ldots+t_{(i-1)}+(n-i+1) t_{(i)}$.

The testing itself is based on putting the values $u_{(i)}$ and $i / n$ in the graph. In case of the IFR distribution the graph $u_{(i)}$ is convex, concerning the DFR distribution the graph is concave.

\section{Example of the application}

The assessed failures were as follow:

a) only mechanical, software and process ones.

b) the failures resulting from shortage of redundant cycles (pyr)

The source of the data is operating data - number of cycles (shots) to failure (mechanical, software, process cause not at all due to shortage of redundant cycles that is pyrotechnical cartridge) regarding sixteen observed systems.

Ad a) The data used for the analysis are put in table 1, the data in red stand for censoring by time and not the failure. Complete enumeration consists of a number of shots to failure regarding sixteen renewed systems of the same type (cannon). In the paper there is presented only one system how to carry out the method. The data is arranged according to its real occurrence and is essential for quite a few of non-parametric tests. The values are modified owing to industrial protection. The thick blue line separates the years 2005, 2006.

Table 1: Data from system operation

\begin{tabular}{|c|ccccc|cccccc|}
\hline Cannon & \multicolumn{10}{|c|}{$t_{i}-$ time to failure } \\
\hline 1 & 201 & 339 & 660 & 512 & 156 & 1293 & 2 & 4 & 2 & 200 & 798 \\
\hline
\end{tabular}

Table 2 shows the calculation of the Nelson-Altschuler estimator of cumulative hazard function $\Lambda_{T}^{*}(t)$. 
Table 2: Table of Nelson-Altschuler Estimation calculation

\begin{tabular}{|c|c|c|c|c|c|c|c|c|c|c|c|c|}
\hline \multirow{2}{*}{$\begin{array}{c}\text { Event } \\
\text { (i) }\end{array}$} & \multirow{2}{*}{$\begin{array}{c}\text { Time } \\
t_{(i)}\end{array}$} & \multirow{2}{*}{$\begin{array}{c}\text { Failure } \\
\qquad[i]\end{array}$} & \multirow{2}{*}{$\begin{array}{l}\text { Rate } \\
m_{[i]}\end{array}$} & \multirow{2}{*}{$\begin{array}{c}\text { Risk } \\
\text { set } \\
r_{[i]}\end{array}$} & \multicolumn{8}{|c|}{ Nelson-Altschuler Data } \\
\hline & & & & & $\begin{array}{c}\Lambda \\
\left(t_{[i]}\right)\end{array}$ & D_ $\Lambda$ & $\mathrm{H}_{\Lambda}$ & $\begin{array}{c}R \\
\left(t_{[i]}\right)\end{array}$ & $\mathrm{D}_{R}$ & $\stackrel{\mathrm{H}}{R}$ & $\begin{array}{l}\text { Var } \\
(\Lambda)\end{array}$ & $u_{(i)}$ \\
\hline $1-2$ & 2 & 1 & 2 & 61 & 0,033 & $\begin{array}{c}0,00 \\
0 \\
0,00\end{array}$ & $\begin{array}{c}0,07 \\
8 \\
0,10\end{array}$ & 0,968 & 0,925 & 1,0 & $10^{-3}$ & 0,003 \\
\hline 3 & 4 & 2 & 1 & 59 & 0,050 & 0 & 6 & 0,951 & 0,899 & 1,0 & $10^{-3}$ & 0,007 \\
\hline
\end{tabular}

Description of the table:

Event $(i)$ - serial number of an event (failures including possible censoring by time).

Time $t_{(i)}$ - times to failure and possible censoring by time arranged upwardly.

Failure $[i]$ - serial number of the failure.

Rate $m_{[i]}$, Risk set $r_{[i]}-$ see (2) and its description.

Values in the column $\Lambda\left(t_{[i]}\right)$ are calculated according to (2) and they are point estimator of cumulative hazard function in the interval $\left(t_{[i-1]}, t_{[i]}\right\rangle$. The values $\mathrm{D}_{-} \Lambda, \mathrm{H} \_\Lambda$ are relevant lower and upper limits of $95 \%$ of the dependability interval.

The values put in the column called $R\left(t_{[i]}\right)$ are point estimator of reliability function in the interval $\left\langle t_{[i-1]}, t_{[i]}\right)$. The calculation follows the well known formula $R(t)=e^{-\Lambda(t)}$.

The column $u_{(i)}$ - the values of test statistic for TTT are calculated using (5). Figures 1 and 2 show the course (typically stepped function) of the estimators $\Lambda_{T}^{*}(t)$ and $R_{T}^{*}(t)$, including relevant $95 \%$ of confidence limits. The course of the estimator of reliable operation probability R1(t) and its $95 \%$ of the confidence limits $(\mathrm{D}(t)-$ the course of the lower limit $\mathrm{H}(t)-$ the course of the upper limit) is put in figure 1. 


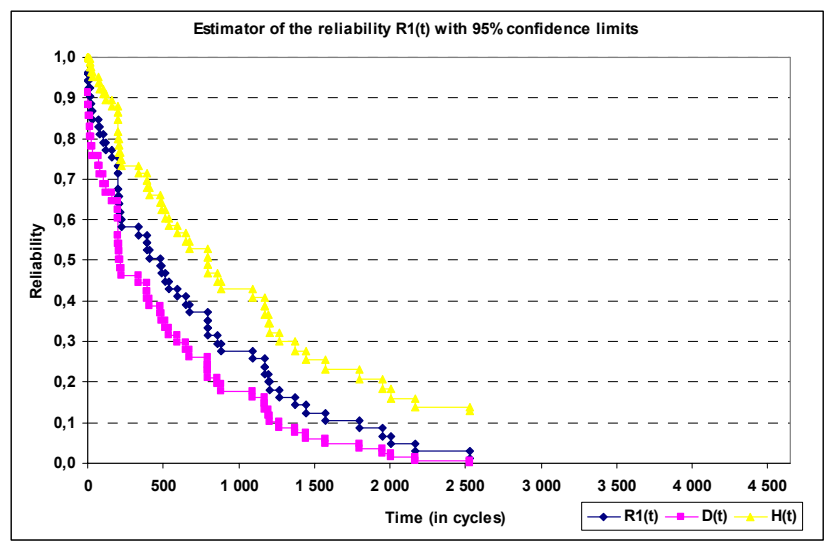

Figure 1: Reliability of the system and its $95 \%$ confidence intervals

Ad b) This time the data in table 3 contains number of cycles to failure owing to shortage of redundant cycles, the data in red shows the information on censoring by time. By way of demonstration there is also one system only which is supposed to demonstrate how to carry out the method. The values are again modified due to industrial protection.

Table 3: Data from system operation censored by lack of cycles

\begin{tabular}{|c|ccc|}
\hline System & Number of main cycles to failure & \\
\hline 1 & 1200 & 668 & 2299 \\
\hline
\end{tabular}

Even in this case the NA non-parametric estimation of cumulative failure rate $\Lambda_{2}(t)$ was used in order to estimate reliable operation probability. The example of calculation results is put in table 4 .

Table 4: Table of Nelson-Altschuler Estimator calculation

\begin{tabular}{|c|c|c|c|c|c|c|}
\hline$t_{[i]}$ & $\Lambda_{2}\left(t_{5 i 1}\right)$ & $\mathrm{D} \Lambda_{2}\left(t_{[i]}\right)$ & $\mathrm{H} \Lambda_{2}\left(t_{[i]}\right)$ & $R_{2}\left(t_{[i]}\right)$ & $\mathrm{D} R_{2}\left(t_{[i]}\right)$ & $\mathrm{H} R_{2}\left(t_{[i]}\right)$ \\
\hline 76 & 0,0385 & 0,0000 & 0,1138 & 0,9623 & 0,8924 & 1,0000 \\
\hline 149 & 0,0785 & 0,0000 & 0,1872 & 0,9245 & 0,8293 & 1,0000 \\
\hline 236 & 0,1201 & 0,0000 & 0,2561 & 0,8868 & 0,7740 & 1,0000 \\
\hline
\end{tabular}

The course of the estimator of the reliability function $R_{2}(t)$ and its $95 \%$ confidence limits $(D(t)$ - lower limit, $H(t)$ - upper limit) is put in graph 2 . 


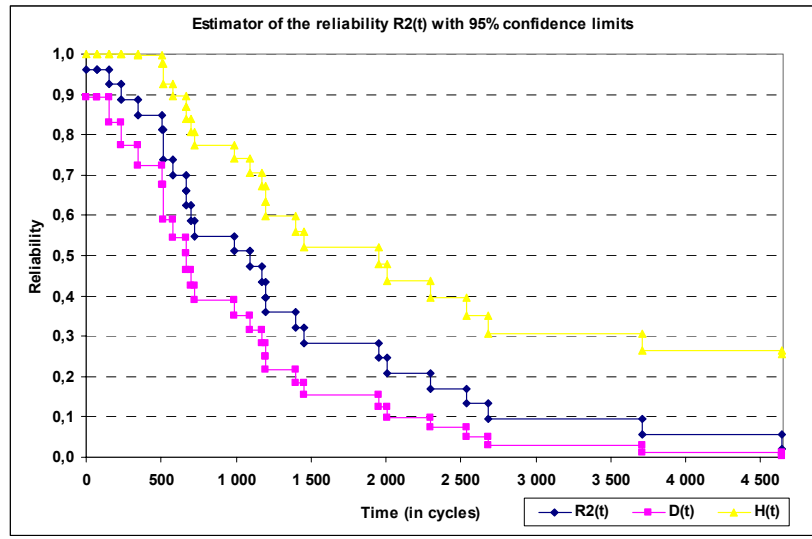

Figure 2: Reliability of the system and its $95 \%$ confidence intervals

Last but not least, it is necessary to carry out the test which shows us whether the courses $R_{1}(t)$ and $R_{2}(t)$.are consistent. From the operational point of view it is important to assess the impact of both types of failures (mechanical-software-process, or shortage of redundant cycles) they made on the reliability of the analysed system. The courses of both reliability functions $R_{1}(t)$ and $R_{2}(t)$ are put in figure 3. Mathematically this issue is supposed to result in a statistical test.

$$
H_{0}: R_{1}(t)=R_{2}(t) \quad \times \quad H_{1}: R_{1}(t) \neq R_{2}(t)
$$

With the respect to the nature of the data the non-parametric Mantel's test (N. Mantel: Evaluation of survival data and two new rank order statistics arising from its consideration. Cancer Chemother. Rep., 50, 163-170) was selected. When we apply the test to the data described above, we come to the conclusion that the impact of mechanical-software-process failures on system reliability is statistically a lot higher than the impact of the failures due to shortage of redundant cycles (pyrotechnical cartridges). This is also the case of the modified data. 


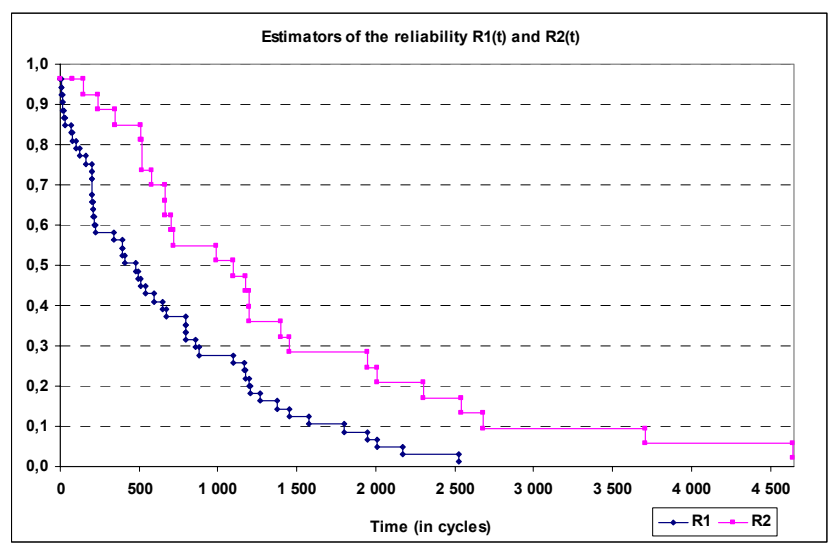

Figure 3: Reliability comparation of the $\mathrm{R}_{1}(\mathrm{t})$ a $\mathrm{R}_{2}(\mathrm{t})$ functions

\section{Conclusions}

In the paper we wanted to shed light on evaluating quite specific technical systems which, by all means, are present in different processes. Since they are specific both by their construction and the way they work, then the analysis of their properties might not be standard either. So far some ways of finding optimum construction arrangements in order to obtain a required level of dependability and function have been shown. The method we chose is aimed at verifiable evaluation of the real data obtained from operation by using appropriate methods. Both the mathematical model and the example of a practical application together with operational data reflect the behaviour of the real system. The graphs covering the courses help us to catch the behaviour of the system even more precisely. On the basis of this information it is quite easy to get reliability measures as well as availability measures of the system where the parameter is discreet there and it is given by a number of cycles the system performs during its function.

\section{Acknowledgements}

This paper has been prepared with great support of the Ministry of Education, Youth and Sports of the Czech Republic, project No. 1M06059 - Advanced Technologies and systems for Power Engineering. 


\section{References}

1. AKERSTEN, P.A.: "The Double TTT-Plot - a Tool for the Study of Nonconstant Failure Intensities", In: Proceedings of the $6^{\text {th }}$ National Reliability Conference in Birmingham. Warrington: National Centre of System Reliability UKAEA 2B/3/1-8, 1987.

2. CROWDER, M. J., KIMBER, A. C.: Statistical Analysis of Reliability Data, London: Chapman \& Hall, 1991.

3. NELSON, W.: Hazard Plotting of Left Trucated Life Data, Journal of Quality Technology Nr. 20, 1990, pp. $230-238$.

4. KOUCKY, M., VALIS, D.: Reliability of Sequential System with Restricted Number of Renewals. In: Risk, Reliability and Social Safety. London: Taylor \& Francis, 2007. pp. 1845 - 1849. 


\section{PŘÍSPĚVEK K HODNOCENÍ POHOTOVOSTI SLOŽITÝCH SYSTÉMŮ S PRVKY JEDNORÁZOVÉHO POUŽITÍ}

\section{Introduction}

Tento př́spěvek má přispět $\mathrm{k}$ možnostem řešení vlastností spolehlivosti složitých (zbraňových) systémů - sledovaný objekt. Rádi bychom prezentovali způsob pro specifikaci hodnoty celkové spolehlivosti kompletu. Cílem př́spěvku je verifikace navrhovaného řešení ve vztahu k některým funkčním elementům, které výrazným způsobem mohou ovlivnit splnění požadované funkce . [4]

Př́spěvek se zabývá zbraňovým kompletem jako komplexním mechatronickým systémem, který je navržen a zkonstruován pro vojenské účely. Hovoř́me o hlavňové palné zbrani - rychlopalný dvouhlavňový kanón. Předpoklad použití je v prostředí vzdušných sil.

Obecně lze charakterizovat, že komplet sestává z mechanických, elektrických, elektronických a silových částí a munice. Pro potřeby tohoto př́spěvku předpokládáme, že se budeme zabývat pouze izolovanými funkčními bloky a municí. V našem případě uvažujeme tedy munici jako klíčový element sestávající ze standardizovaných nábojů a pyrotechnických nábojek.

Vlastnosti jakosti jednotlivých součástí kompletu mohou být popsány jak kvalitativními tak kvantitativními charakteristikami .V prŕspěvku se zabýváme především vlastnostmi spolehlivosti. Dále zdůrazňujeme, že pracujeme převážně s charakteristikami a hodnotami pravděpodobnosti, které charakterizují jednotlivé procesy a popisují funkční rozsah a požadované funkční schopnosti kompletu. Naproti tomu se nezabýváme pouze zacházením s náboji a pyrotechnickými nábojkami jakkoliv se tato část může zdát jako klíčová. Pro další práci je potřeba definovat některé pojmy a specifikovat obsah funkcí

Hlavním typem dat, která mohou být nalezena v oblasti statistických analýz spolehlivosti jsou následující: jednoduchá, censurovaná, ořezaná (redukovaná), anebo jejich kombinace. 
Jednoduchá data: jedná se o základní kategorii, ve které je získaná informace $t_{1}, t_{2}, \ldots, t_{n}$ souborem rozdělení pravděpodobnosti doby do poruch $T$.

Censurovaná data: data jsou vyjádřena v podobě $\left(t_{1}, d_{1}\right), \ldots,\left(t_{n}, d_{n}\right)$, kde $t_{i}$ $=\min (T, C), T$ je náhodná proměnná určující dobu do poruchy, $C$ je censurovaný čas a $d_{i}$ je indikátor definovaný vztahem $d_{i}=1 \mathrm{v}$ př́padě že $t_{i}$ doba do poruchy a $d_{i}=0 \mathrm{v}$ ostatních př́padech. Základní typy zahrnují censurování pevným časem ( $C$ je fixní čas) anebo náhodným časem $(C$ je náhodná proměnná $s$ daným rozdělením pravděpodobnosti). Tento typ dat bezporuchovosti je často používán v praxi a může být nalezen v situacích kdy je sledovaný čas ukončen po nějaké době, protože systém je vyřazen z provozu, apod. S ohledem na laboratorní zkoušky se tato oblast nazývá „zkoušky ukončené časem“.

Ořezaná data: Toto jsou data o poruše, která jsou zaznamenána po uplynutí určité doby. V praxi se někdo může dostat do kontaktu s takovými druhy dat pokud není informace o poruchách sdělena v počátečních fázích. Klasifikace statistických metod použivaných ve statistických analýzách spolehlivosti:

Parametrické metody:tyto metody jsou vytvořeny na předpokladu, že sledovaná data odrážejí náhodný výběr specifického druhu rozdělení (exponenciální, Weibullovo, gama, tec.). Hlavním úkolem je potom určení (odhad) hodnot neznámých parametrů založených na pozorovaných datech.

Neparametrické metody: tyto metody neberou $v$ úvahu žádnou specifickou klasifikaci dat a jsou více „universální“ a jistou alternativou k parametrickým metodám (což je hlavní výhoda). Hlavní nevýhodou je je jejich menší „síla“ (v porovnání s parametrickými metodami).

Smi-parametrické metody: tyto metody, které jsou jakýmsi kompromisem mezi parametrickými a neparametrickými metodami, požadují pouze „č́stečnou“ specifikaci druhu rozdělení. Parametrický model je uveden pro důležité proměnné a neparametrický pro proměnné nízké důležitosti.

\section{Důležité pojmy, definice a označení}

Ve smyslu analýz bezporuchovosti hovoříme stále o objektu. Definice odpovídá zdroji IEC 60050 (191/50). Následně je nutné popsat základní vlastnosti objektu. [4];

Funkce objektu: 
Hlavní funkce: Hlavní funkce objektu je výstřel zbraně za využití standardizované munice.

Vedlejší funkce: Manipulace s municí, nabíjení, iniciace, detekce a indikace poruchy munice během inicializace, inicializace záložního podpůrného systému (určeného pro přebíjení porouchaného náboje).

Předpokládáme, že objekt bude schopen fungovat za různých provozních podmínek obzvlášt' $\mathrm{v}$ různých teplotních spektrech, pod vlivem různých statických, kinetických a dynamických podmínek, v různých zónách atmosférických a povětrnostních podmínek.

V našem př́ípadě nebudeme brát do úvahy žádný z výše uvedených vlivů. Naproti tomu jejich vliv může být velmi důležitý s ohledem na úspěšné splnění mise.

Jeden z hlavních pojmů, který dále rozvineme je:

Mise/mission: jedná se o schopnost splnit určený úkol objektem $\mathrm{v}$ specifikovaném čase, za stanovených podmínek a v požadované kvalitě.

$\mathrm{V}$ prŕípadě našeho př́íspěvku se jedná o schopnost kanónu vystřelit požadovaný počet nábojů na cíl v požadovaném čase, za daných provozních podmínek a podmínek prostředí.

Tak jak je zrrejmé $\mathrm{z}$ definice jedná se o prrípad kdy komplet fungující v různých podmínkách splnil naše požadavky ve smyslu plného uspokojení požadavků.

Náš objekt má být schopen vystřelit požadované množství munice a má zasáhnout cíl s požadovanou přesností (pravděpodobností). Do úvahy zde nebereme okolnosti vyhodnocení střelby, cílení zbraně, vnitřní a vnější balistiky, povětrnostních podmínek a jiné. Budeme se soustředit pouze na schopnost objektu stř́let. [4]

Dále dle výše uvedeného se nebudeme zabývat izolovanými funkčními bloky. Předpokládáme, že tyto bloky fungují podle požadovaných a stanovených okrajových podmínek. Pro potřeby plného pochopení funkčních vazeb, zavádíme zde jakýsi způsob rozdělení objektu ačkoliv objekt pořád vnímáme jako jeden složitý systém.

Hovoříme o následujících blocích:

Manipulace s municí, její nabíjení, inicializace, detekce poruch a indikace během inicializace, inicializace záložního podpůrného systému ve smyslu znovu nabití porouchaného náboje, všechny elektrické, elektronické a mechanické části plus rozhraní s nosičem - Blok - A;

Munice - Blok B;

Pyrotechnické nábojky - blok C. 
Symboly použité v textu:

$T$ náhodná proměnná vyjadřující dobu do poruchy, $t_{1}, t_{2}, \ldots, t_{n}$ sledované hodnoty náhodné proměnné $T$ (což je náhodný vzorek $T$ ), nebo data na možné censurování, $t_{(1)}, t_{(2)}, \ldots, t_{(n)}$ uspořádané hodnoty $t_{1}, t_{2}, \ldots, t_{n}$ (včetně dat na censurování), $t_{[1]}, t_{[2]}, \ldots \quad$ uspořádaný náhodný vzorek dob do poruchy, to znamená, bez censurovaných dat,

$\Lambda_{T}(t), \Lambda_{T}^{*}(t) \quad$ kumulativní intenzita poruch nebo její bodový odhad, $R_{T}(t), R_{T}^{*}(t) \quad$ funkce bezporuchovosti nebo její bodový odhad, $E[\bullet], E^{*}[\bullet] \quad$ střední hodnota náhodné proměnné nebo její bodový odhad, $\operatorname{var}[\bullet] \operatorname{var}^{*}[\bullet]$ rozptyl nebo jeho bodový odhad $\bullet$.

\section{Popis procesu}

Proces lze popsat následovně:

Z matematického i technického pohledu se jedná o uspokojení proudu požadavkủ, které postupně přicházejí do místa obsluhy - nábojová komora. Proud požadavků je v našem př́padě diskrétní nábojový pás kde náboje čekají na svůj okamžik použití, přičemž jsou transportovány z z místa fronty do prostoru místa služby - nábojové komory (splnění požadavku) zde jsou potom následně iniciovány. Po iniciaci je požadavek uspokojen. Prázdná nábojnice odchází jinou cestou než kompletní náboj. Jestliže je proces uspokojen, jiný systém, schopný identifikovat tento jev, detekuje úspěšné splnění požadavku. Tento proces je detekován a indikován na bázi vzájemně propojených reakcí. V prŕípadě kanónu je uspokojení procesu identifikováno jako pohyb závěru hlavně zbraně vzad. Jak splnění požadavků a jejich detekce jsou spojeny s dopravou dalšího náboje čekajícího v linii na to, až se dostane do komory.

Předpokládejme, že náboje jsou umístěny $v$ nábojovém pásu přesně definované délky. Tím je dáno, že maximální délka pásu (cyklů) je přesně daná a limitovaná. Délka je tedy dána bud' konstrukčními omezeními anebo taktickými a technickými požadavky na komplet.

Předpokládejme, že bez ohledu na délku nábojového pasu tento bude vždy plněn od začátku do konce. Dalším předpokladem je, že munice je standardizovaná a je navržena pro tento komplet. 
Proces splnění požadavku je monitorován jiným systémem, který je schopen rozlišit zda byl požadavek splněn nebo ne. Správná posloupnost procesu je popsána výše. S ohledem na možnou poruchovost nábojů je systém právě vybaven dalším systémem pro detekci porouchaného náboje (tzn. náboj je dopraven do komory, je iniciován, ale není odpálen). Důležitá funkce pro opuštění náboje nábojovou komoru není tedy uskutečněna a proto všechny ostatní náboje čekající ve frontě nemohou být dopraveny do místa obsluhy. Systém je jak již bylo řečeno schopen takovou událost detekovat a učinit určitá proti-opatření. Záložní systém (částečně popsaný výše) je iniciován. Je-li náboj iniciován, ale nenásledujíc žádné další kroky (žádný výstřel, žádný pohyb závěru vzad-tedy žádná detekce splnění požadavku, neopuštění prázdné nábojnice nábojové komory a žádný posun nového náboje do nábojové komory) poté je okamžitě iniciován systém pyrotechnických nábojek. Tento podpůrný systém je propojen se všemi důležitými systémy, které zajišt'ují splnění mise. Poškozený proud požadavků je tedy obnoven a další náboj je dopraven do komory.

Pro možnost obnovení hlavní funkce používáme určitý počet podpůrných pyrotechnických nábojek. Naším úkolem je stanovit minimální možný potřebný počet pyronábojek, který dostačuje pro úspěšné splnění mise. Dalším požadavkem je nalezení funkce pohotovosti systému. Rádi bychom totiž věděli, zda je systém schopen pokračovat $v$ plnění mise na základě své historie. Především nás zajímá, zda jsou „zbývající“ provozní jednotky dostatečné pro splnění následné mise bez jakýchkoliv nutných technických zásahů do systémy ve smyslu výměny/údržby. Jelikož máme $\mathrm{k}$ dispozici data $\mathrm{s}$ předešlého nasazení systému jsme schopni je vyhodnotit za využití matematických nástrojů. S ohledem na specifickou funkční a konstrukční strukturu systému se jeví jako vhodné použít jiné než standardní metody analýzy. Následující část je příkladem našeho snažení [4].

\section{Matematický model}

Pro analýzu dostupných dat provozu o jeho chování použijeme dvě metody vhodné pro jejich kvalitní zpracování. První z nich je Nelson-Altschuler estimator [1], [2], [3]. Jedná se o př́pad základní neparametrické metody, která je použita pro statistické analýzy bezporuchovosti, obzvláště pokud hovoříme o kumulativní intenzitě poruch $\Lambda_{T}(t)$, která je definována následujícím vztahem: 
$\Lambda_{T}(t)=\int_{0}^{t} \lambda_{T}(u) d u$

kde $\lambda_{T}(t)$ je intenzita poruch v čase $t$, tedy $\lambda_{T}(t)=\lim _{h \rightarrow 0+} \frac{P(t \leq T<t+h \mid t \leq T)}{h}$

Předpokládejme, že získaná data o spolehlivosti $t_{1}, t_{2}, \ldots, t_{n}$ jsou informace o době do poruchy nebo informace o čase censurování. $\mathrm{V}$ tomto př́padě je Nelson-Altschulerův bodový odhad $(\mathrm{N}-\mathrm{A}) \Lambda_{T}^{*}(t)$ kumulativní intenzity poruchy vyjádřen jako:

$$
\Lambda_{T}^{*}(t)=\sum_{\substack{\left.[i] \\ t_{i j}\right] \leq t}} \frac{m_{[i]}}{r_{[i]}},
$$

kde $t_{[i]}$ je $i$-tý prvek uspořádaného náhodného vzorku dob do poruchy (to znamená, že nezahrnujeme censurovaný čas do výběru), $m_{[i]}$ je frekvence hodnoty $t_{[i]}, \eta_{i]}$ je počet objektů v provozu v čase $t_{[i]}$.

Pokud se porucha vyskytne spolu s censurováním, předpokládáme, že se censurování objeví přímo po poruše. Pro vyjádření rozptylu $\Lambda_{T}^{*}(t)$ použijeme asymptotický výraz:

$$
\operatorname{var}^{*}\left[\Lambda_{T}^{*}(t)\right]=\sum_{\substack{[i] \\\left[_{i j}\right] \leq t}} \frac{m_{[i]}}{\eta_{i]}^{2}},
$$

díky němu můžeme vyjádřit konfidenční limity. Pro $(1-\alpha) \%$ dostaneme konfidenční limity hodnoty $\Lambda_{T}^{*}(t)$ :

$$
\left(\Lambda_{T}^{*}(t)-u_{1-\alpha / 2} \sqrt{\operatorname{var}^{*}\left[\Lambda_{T}^{*}(t)\right]}, \Lambda_{T}^{*}(t)+u_{1-\alpha / 2} \sqrt{\operatorname{var}^{*}\left[\Lambda_{T}^{*}(t)\right]}\right),
$$

kde $u_{\alpha}$ je $\alpha \%$ kvantil standardního normálního rozdělení.

Samozřejmě, že zde může být velká množina možných výběrů neparametrických metod, které jsou založeny na hodnocení spolehlivosti $\mathrm{z}$ dat $\mathrm{z}$ provozu. Mezi jinými můžeme zmínit neparametrické odhady hustoty obnovy, funkce obnovy a neparametrické zkoušky trendů vývoje. Jinou metodou používanou pro hodnocení systémů je stanovení rozdělení doby do poruchy a jeho vlastností. Tento se nazývá statistický test TTT (Total Time on Test-plot), který umožňuje rozhodnout o tom, zda je rozdělení doby do poruchy a jeho intenzita stoupající (IFR - Increasing Failure Rate), nebo klesající (DFR - Decreasing Failure Rate). 
Jestliže $t_{(1)}, t_{(2)}, \ldots, t_{(n)}$ je uspořádaný vzorek dob do poruchy, potom je statistika zkoušek $u_{(i)}$ definována následovně.

$u_{(i)}=\frac{T_{i, n}}{T_{n, n}}$,

kde $T_{i, n}=t_{(1)}+t_{(2)}+\ldots+t_{(i-1)}+(n-i+1) t_{(i)}$.

Vlastní testování je založeno na principu umístění hodnot $u_{(i)}$ a $i / n$ do grafu. V případě rozdělení IFR je graf $u_{(i)}$ konvexní a $\mathrm{v}$ př́ípadě DFR rozdělení je graf konkávní.

\section{Př́́klad aplikace}

Hodnocené poruchy byla následující:

a) pouze mechanické, softwarové a procesní.

b) Poruchy vyplývající z nedostatku záložních cyklů (pyr)

Zdrojová data jsou informace z provozu - -počet cyklů (výstřelů) do poruchy (mechanické, softwarové, procesní nejenom z důvodu nedostatku záložních cyklů pyr) od šestnácti sledovaných kompletů.

Ad a) Data použitá $v$ analýze jsou demonstrována $v$ tabulce 1 , červeně označená data znamenají censurování časem nikoliv poruchou. Kompletní přehled sestává $\mathrm{z}$ počtu výstřelů do poruchy u šestnácti obnovovaných systémů stejného typu (kanón). Zde uvádíme pouze jeden systém pro demonstraci metody. Data jsou seřazena sohledem na jejich skutečný výskyt a jsou vhodná právě ve svém počtu pro ne-parametrické testy. Data jsou mírně modifikována s ohledem na průmyslové tajemství a tlustá modrá čára odděluje roky 2005 a 2006.

Tabulka 1: Data z provozu kompletu

\begin{tabular}{|c|ccccc|cccccc|}
\hline Kanón & \multicolumn{11}{|c|}{$t_{i}$-doba do poruchy } \\
\hline 1 & 201 & 339 & 660 & 512 & 156 & 1293 & 2 & 4 & 2 & 200 & 798 \\
\hline
\end{tabular}

Tabulka 2 znázorňuje výpočet Nelson-Altschulerova odhadu pro kumulativní intenzitu poruchy $\Lambda_{T}^{*}(t)$. 
Tabulka 2: Tabulka výpočtu Nelson-Altschulerova odhadu

\begin{tabular}{|c|c|c|c|c|c|c|c|c|c|c|c|c|}
\hline \multirow{2}{*}{$\begin{array}{c}\text { Událost } \\
\text { (i) }\end{array}$} & \multirow{2}{*}{$\begin{array}{c}\text { Čas } \\
t_{(i)}\end{array}$} & \multirow{2}{*}{$\begin{array}{c}\text { Porucha } \\
{[i]}\end{array}$} & \multirow{2}{*}{$\begin{array}{l}\text { Int. } \\
m_{[i]}\end{array}$} & \multirow{2}{*}{$\begin{array}{c}\text { Riziko } \\
r_{[i]}\end{array}$} & \multicolumn{6}{|c|}{ Nelson-Altschulerova Data } & \multirow[b]{2}{*}{$\begin{array}{l}\text { Var } \\
(\Lambda)\end{array}$} & \multirow[b]{2}{*}{$u_{(i)}$} \\
\hline & & & & & $\begin{array}{c}\Lambda \\
\left(t_{[i]}\right. \\
\end{array}$ & D_ $\Lambda$ & $\begin{array}{c}\mathrm{H}_{-} \\
\Lambda\end{array}$ & $\begin{array}{c}R \\
\left(t_{[i]}\right) \\
\end{array}$ & $\mathrm{D}_{-}$ & $\begin{array}{r}\mathrm{H}_{-} \\
R\end{array}$ & & \\
\hline & & & & & 0,0 & 0,00 & 0,07 & & & 1,0 & & 0,0 \\
\hline $1-2$ & 2 & 1 & 2 & 61 & $\begin{array}{c}33 \\
0,0\end{array}$ & $\begin{array}{c}0 \\
0,00\end{array}$ & $\begin{array}{c}8 \\
0,10\end{array}$ & 0,968 & 0,925 & $\begin{array}{l}00 \\
1,0\end{array}$ & $10^{-3}$ & $\begin{array}{c}03 \\
0,0\end{array}$ \\
\hline 3 & 4 & 2 & 1 & 59 & 50 & 0 & 6 & 0,951 & 0,899 & 00 & $10^{-3}$ & 07 \\
\hline
\end{tabular}

Popis tabulky:

Událost $(i)$ - pořadové číslo události (události obsahující možné censurování časem).

Čas $t_{(i)}$ - doba do poruchy a možné censurování časem seřazené vzestupně.

Porucha $[i]$ - pořadové číslo poruchy.

Intenzita $m_{[i]}$, množina rizika $r_{[i]}-\operatorname{viz}(2)$ a její popis.

Hodnoty ve sloupci $\Lambda\left(t_{[i]}\right)$ jsou vypočteny podle (2) a jedná se o bodové odhady kumulativní intenzity poruchy pro interval $\left\langle t_{[i-1]}, t_{[i]}\right\rangle$. Hodnoty jsou relevantní dolní a horní konfidenční intervaly pro 95\% spolehlivost.

Hodnota ve sloupci $R\left(t_{[i]}\right)$ je bodovým odhadem funkce bezporuchovosti na intervalu $\left(t_{[i-1]}, t_{[i]}\right\rangle$. Výpočet je proveden podle známého vztahu $R(t)=e^{-\Lambda(t)}$.

Sloupec $u_{(i)}$ - je hodnota testu TTT a je vypočtena podle (5). Obrázky 1 a 2 znázorňují průběh funkce (typicky schodovité) odhadu $\Lambda_{T}^{*}(t)$ a $R_{T}^{*}(t)$ včetně 95\% spolehlivostních intervalů.

Průběh odhadu pravděpodobnosti bezporuchového provozu a její 95\% konfidenční intervaly $\mathrm{D}(t)$ - průběh dolního limitu a $\mathrm{H}(t)$ - průběh horního limitu jsou uvedeny v obrázku 1 . Kde reliability = bezporuchovost; Time (in cycles) $=$ doba $v$ počtech cyklů. 


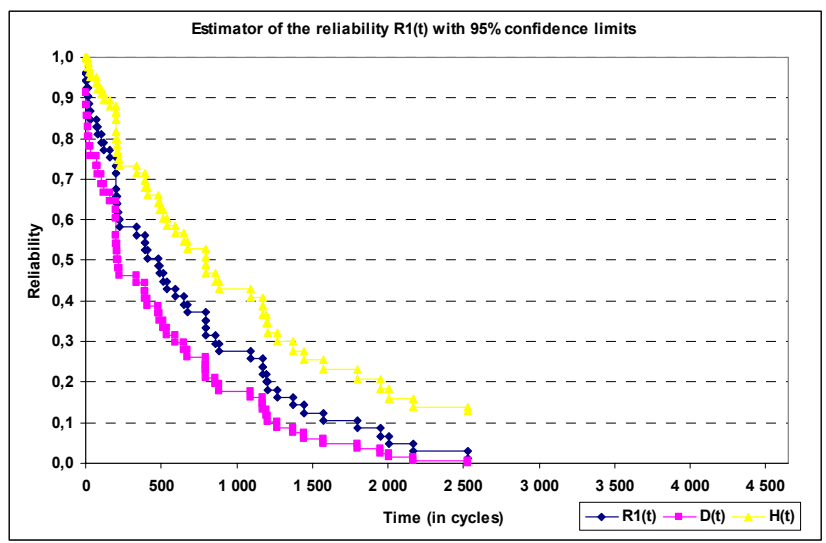

Obrázek 1: Bezporuchovost systému a jeho 95\% intervaly spolehlivosti

Ad b) V tomto případě data obsažená v tabulce 3 představují počet cyklů uskutečněných až do vyčerpání záložních. Červeně označená data představují censurování časem. Pro demonstraci metody je zde rovněž uveden pouze jeden systém. Hodnoty jsou rovněž modifikovány s ohledem na průmyslové tajemství.

Table 3: Data z provozu systému censurována nedostatkem záložních cyklů

\begin{tabular}{|c|ccc|}
\hline System & Number of main cycles to failure \\
\hline 1 & 1200 & 668 & 2299 \\
\hline
\end{tabular}

Také v tomto prŕípadě byla použita metoda NA neparametrického odhadu pro kumulativní intenzitu poruch $\Lambda_{2}(t)$ pro určení pravděpodobnosti bezporuchového provozu.

Table 4: Tabulka výpočtu Nelson-Altschulerova odhadu

\begin{tabular}{|c|c|c|c|c|c|c|}
\hline$t_{[i]}$ & $\Lambda_{2}\left(t_{[i]}\right)$ & $\mathrm{D} \Lambda_{2}\left(t_{[i]}\right)$ & $\mathrm{H} \Lambda_{2}\left(t_{[i]}\right)$ & $R_{2}\left(t_{[i]}\right)$ & $\mathrm{D} R_{2}\left(t_{[i]}\right)$ & $\mathrm{H} R_{2}\left(t_{[i]}\right)$ \\
\hline 76 & 0,0385 & 0,0000 & 0,1138 & 0,9623 & 0,8924 & 1,0000 \\
\hline 149 & 0,0785 & 0,0000 & 0,1872 & 0,9245 & 0,8293 & 1,0000 \\
\hline 236 & 0,1201 & 0,0000 & 0,2561 & 0,8868 & 0,7740 & 1,0000 \\
\hline
\end{tabular}

Průběh odhadu funkce spolehlivosti $R_{2}(t)$ a jejího $95 \%$ intervalů spolehlivosti $(D(t)$ - dolní mez; $H(t)$ - horní mez) je uvedena v grafu 2. Kde reliability $=$ bezporuchovost; Time $($ in cycles $)=$ doba $\mathrm{v}$ počtech cyklů. 


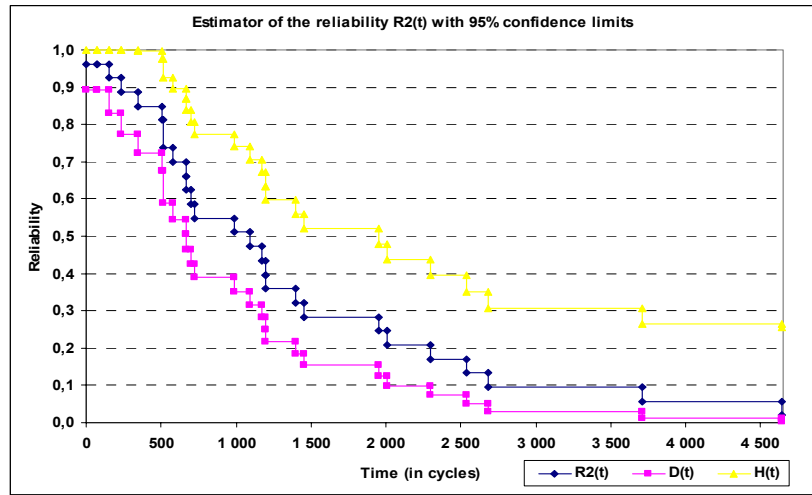

Obrázeke 2: Bezporuchovost systému a jeho 95\% konfidenční intervaly

Konečně, je také potřebné provést test, který nám prokáže zda jsou průběhy $R_{1}(t)$ a $R_{2}(t)$ konsistentní. Z provozního hlediska je nutné hodnotit dopady obou typů poruch (mechanicko-softwarovo-procesní, nedostatek záložních cyklů), které mají vliv na hodnotu bezporuchovosti analyzovaného systému. Průběh obou funkcí spolehlivosti je uveden v obrázku 3 (Kde reliability = bezporuchovost; Time (in cycles) = doba $\mathrm{v}$ počtech cyklů.). $\mathrm{Z}$ matematického pohledu je možné tento předpoklad vyjádřit statistickým testem.

$$
H_{0}: R_{1}(t)=R_{2}(t) \quad \times \quad H_{1}: R_{1}(t) \neq R_{2}(t)
$$

$\mathrm{S}$ ohledem na povahu neparametrických dat Mantelova testu (N. Mantel: Evaluation of survival data and two new rank order statistics arising from its consideration. Cancer Chemother. Rep., 50, 163-170) byla tato data vytříděna. Pokud aplikujeme tento druh testu na shora uvedená data zjistíme, že dopad mechanicko-softwarovo-procesních chyb na systém je statisticky mnohem vyšší než dopad poruch z nedostatku záložních cyklů. Tento príípad platí i pro modifikovaná data.

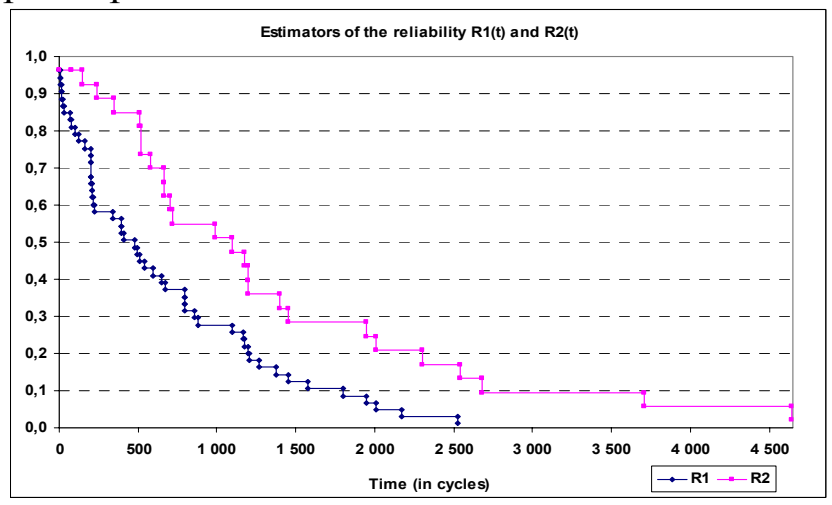

Obrázek 3: Porovnání funkcí spolehlivosti $\mathrm{R}_{1}(\mathrm{t})$ a $\mathrm{R}_{2}(\mathrm{t})$ 


\section{Závěr}

$\mathrm{V}$ tomto př́spěvku jsme chtěli prezentoval přístup $\mathrm{k}$ hodnocení bezporuchovosti technicky velmi specifického systému, jehož fungování je navíc spojeno s mnoha rozličnými procesy. Jelikož se systém specifický jak pro svou konstrukci tak pro způsob činnosti, analýza jeho vlastností je také poněkud nestandardní. Doposud byly prezentovány některé konstrukční návrhy, které jednoznačně prokazují dosažení lepších výsledků spolehlivosti. Zvolená metoda je zaměřena na verifikovatelné hodnocení dat získaných z provozu. Jak prezentovaný matematický model tak aplikační prríklad spolu s vyhodnocením provozních dat prokazují chování systému. Grafické průběhy nám napomáhají pojmout chování systému a znázornit jej ještě lépe. $\mathrm{S}$ ohledem na dosažené výsledky je potom poměrně snadné pracovat sukazateli bezporuchovosti a pohotovosti systému, prričemž parametr je diskrétní a hovoří o počtu cyklů, které systému musí během funkce vykonat.

\section{Poděkování}

Tento přispěvek byl připraven za velké podpory Ministerstva školství, mládeže a tělovýchovy, resp. projektu č. 1 M06059-Pokročilé technologie a systémy pro energetiku.
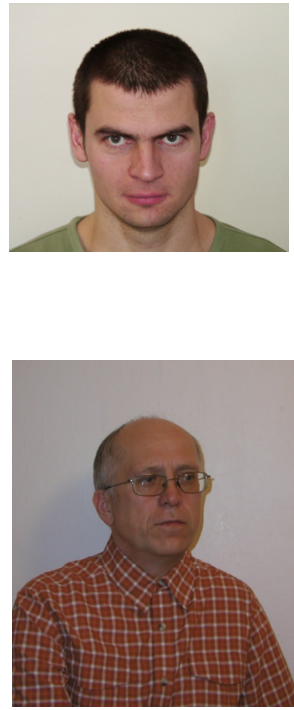

Mr. D. Valis is an assistant professor at the Brno University of Defense. He deals with the branch of technical systems reliability \& maintainability analysis, risk assessment, and vetronics of both military and civilian vehicles. $\mathrm{He}$ is a member of the international standardization organization IEC/ISO in the field of dependability/safety.

\section{Dr. Miroslav Koucký Associate Professor of Theoretical} Cybernetics.

Memberships in professional and technical organisations:

Union of Czech Mathematicians and Physicists. Czech Chamber of Court Expert (reliability analysis, financial mathematics, statistical modelling). Czech Society for Quality.

Main fields of professional interests:

Combinatorics, graph theory, and their applications in reliability (especially reliability of networks, algebraic methods in reliability), multi-states reliability models, k-out-of-n systems, consecutive

systems, Monte Carlo simulations. 